\title{
Measuring EFL Teachers' Implementations of Communicative Language Teaching in Teaching Speaking Skills
}

\author{
Ali Sabah Jameel Al-Khayyat \\ Department of English, College of Arts, University of Anbar, Anbar, Iraq
}

\begin{abstract}
The aim of the study is to investigate EFL teachers' use of Communicative Language Teaching techniques (CLT) in teaching speaking skills at schools from teachers' perspectives. The participants were from the intermediate schools located at AlAmerica District in Baghdad. The total number is 29 EFL male and female teachers. A questionnaire was used to collect the data of the study. Validity and reliability of the questionnaire were computed. The findings reveal that the English language teachers sometimes use CLT Techniques and strategies in teaching speaking skills, and even the students are evaluated even by paper and pencil test more than oral test.
\end{abstract}

Index Terms-EFL teachers, Communicative Language Teaching Approach (CLTA), speaking skills, intermediate school teachers.

\section{INTRODUCTION}

One use language to reflect the physical and psychological appearance; they are closer via the utilization of language. Language can be utilized to express ideas, to exchange information, to have things done and to create images. The main uses of language are to present information, to persuade, to enjoy, to exchange, to express one's feeling and attitudes (Pandey, 2003).

The innovativeness of the 1970s gave affective factors to the forefront of some widely experimental language teaching and learning approaches. The late 1970s and early 1980s have witnessed the starting of what we now call a communicative approach as we better and better comprehend the tasks that must be done into a classroom.

In 1971, a number of experts started to conduct the possibility of improving language classes on a "unit-credit system", a system that learning process can be broken down into "portions or units, each of which corresponds to a component of a learner's needs and is systematically related to all the other portions" (Brown, 2000, p. 17).

Wilkins's contribution was an analysis of the communicative meanings that a language learner needs to understand and express. Rather than describe the core of language through traditional concepts of grammar and vocabulary, Wilkins attempted to demonstrate the systems of meanings that lay behind the communicative uses of language. The work came to be referred to as the Communicative Approach, or simply Communicative Language Teaching. Although the movement starts as a largely British innovation, concentrating on alternative conceptions of a syllabus, since the mid of 70s the field of Communicative Language Teaching has expanded. Both American and British experts now see it as an approach (and not a method) that aims to (1) make communicative competence the goal of language teaching and (2) promote procedures for the teaching of the 4 language skills that knowledge is the interdependence of language and communication. (Wilkins's, 1999)

\section{STATEMENT OF PROBLEM}

The researcher has noticed that the Iraqi English textbooks have been edited for several times and in the past decade or more, the Ministry of Education has adopted new series of English textbooks which are built on the Communicative Language Teaching Approach. After decade of instructions, it is obvious that the Iraqi learners have remained deficient, particularly at literary level, in comprehending spoken or written discourse in English. The "English for Iraq" textbook was therefore introduced at schools level to overcome the communication obstacles. The present study is an attempt to reveal the EFL teachers' actual implementations of Communicative Language Teaching approach inside classrooms in teaching speaking skills; it is an attempt to discover the teachers' real using of communicative approaches, methods, strategies, techniques, and activities in teaching speaking skills.

\section{HYPOTHESIS OF THE STUDY}

The researcher sets the following hypothesis:

There is a high percentage of the teachers' implementations of communicative language teaching approach, strategies, and techniques in teaching speaking skills inside the classroom.

Journal of University of Human Development

Volume 5 No. 3(2019); DOI: 10.21928/juhd.v5n3y2019.pp18-22

Regular research paper: Published 8 July 2019

Corresponding author's e-mail: alisabah40@yahoo.com

Copyright (c) 2019 Ali Sabah Jameel Al-Khayyat. This is an open access article distributed under the Creative Commons Attribution License (CC BY-NC-ND 4.0) 


\section{SIGNIFICANCE OF THE STUDY}

The outcomes and the recommendations of the study can be significant for the curriculum designer, and educational policy maker, and the EFL teachers in Iraq. The study shed the light on the EFL teachers' actual implementations of the speaking skills.

\section{AIMS OF THE STUDY}

The study aims to reveal the extent of implementing communicative practices in teaching speaking skills. That means to find out the EFL actual methods, strategies, and techniques being used in teaching speaking skills.

\section{LIMITS OF THE STUDY}

The study is limited to the following points:

1- Textbooks: the textbooks are the "The New English Course for Iraq".

2- Participants: the participants of the study are from the EFL teachers at intermediate school.

3- Place: the places of the schools are at Amriah District.

4- Time: the study is conducted at the first semester of the academic year 2018-2019.

\section{DEFINITION OF TERMS}

The following are the definition of the basic terms:

1- EFL Teachers: they are teachers who teach English language at schools and university as a foreign language (Tim Borchers, 1999, p.9).

2- Communicative Practices: It means to practice the language by using the features of communicative approach (Wilkins, 1999, p. 15)

3- Speaking Skills: it is one of the four language skills. It also called productive skills (Leng, 1997, p.11).

\section{LITERATURE REVIEW}

Gatbonton, and Segalowitz (2005) investigate teachers' use of CLT. The researcher provide a theoretical analysis that focuses on one of the greatest challenges facing CLT methodology that is 'how to promote automatic fluency within this framework?'. To meet such challenge, the researchers face it by proposing a Communicative Language Teaching methodology designed to fulfill specific criteria that may promote learners' fluency skills. The suggested criteria of the methodology may be operationalized for research purposes. This can help and allow CLT to be evaluated in systematic outcome testing.

Joyce (2005) explored experienced English teachers' knowledge about CLT with their practice in EFL contexts. The research questions in this study were "How do EFL (English as a foreign language) teachers practice CLT in their contexts?" and "Do teachers' beliefs influence their practical knowledge?" The questions attempted to uncover are (a) How do English teachers in EFL contexts implement CLT ideas in their classrooms? (b) What are the typical CLT ideas in their classrooms? (c) What difficulties do they encounter? (d) Will these teachers apply CLT in their future teaching? (e) Where are teachers' beliefs from? And (f) Do teachers' beliefs inform their teaching? Semi structured interviews were conducted with three EFL teachers in Asian countries. Results indicated that teachers' beliefs from their own language learning experience, their teaching experience, and their training inform their instructional practice in CLT. Their practical knowledge is the knowledge that they generate as a result of their experiences as teachers in their own teaching contexts.

Descriptive and inferential analysis of the data indicated that high school and institute teachers' attitudes toward CLT are positive, indicating a welcoming atmosphere toward the implementation of CLT. However, among the participants only the teachers of institutes practice a quasi-CLT type of approach in their classes.

\section{THEORETICAL PERSPECTIVES}

\section{THEORETICAL FRAMEWORK}

Communicative Language Teaching (CLT) is usually characterized as a broad approach to teaching, rather than as a teaching method with a clearly defined set of classroom practices. As such, it is most often defined as a list of general principles or features. One of the most recognized of these lists is Nunan's (1991) five features of CLT:

- An emphasis on learning to communicate through interaction in the target language.

- The introduction of authentic texts into the learning situation.

- The provision of opportunities for learners to focus, not only on language but also on the learning process itself.

- An enhancement of the learner's own personal experiences as important contributing elements to classroom learning.

- An attempt to link classroom language learning with language activities outside the classroom.

These five features are claimed by practitioners of CLT to show that they are very interested in the needs and desires of their learners (Nunan, 1991, p. 11).

Some techniques can be used to develop English language learners' abilities to communicate. The most popular is: "The students in a group should agree on the final decision through discussion and debate". Compromise: Through discussion and readjustment of the final plan, group members come to agreement by giving up some of their demands (Tim, 1999, p.18)

Some of the characteristics of CLT (dialogues, drills, rehearsed exercises, and discussion in the first language of grammatical rules) make it difficult for a nonnative speaking teacher who is not very proficient in the second language to teach effectively. But these should not deter one from pursuing communicative goals in the classroom. Technology (video, television, audiotapes, internet, and computer software) can aid such teachers. (Brown, 2000, p. 23). 


\section{THEORETICAL STUDIES}

Rao (2002) considers the CLTA reception to be lukewarm at best because it challenges traditional cultural beliefs and values and is at odds with traditional relationships between teachers and students. Rao pointed out, further, that emphasis on oral skills may not meet the requirements of curricula in those countries.

Whitley (1993) argues that the needs of teachers have not been well researched and that CLT approaches have not been disseminated in ways which are sensitive to the problems teachers confront in local programs and classrooms.

Kumaravadivelu (1993) concludes that teacher trainers sometimes simply fail to equip teachers with the skills and techniques they need for implementing CLT in their classrooms.

Savignon (2002) holds that teacher education in the use of CLT approaches has not received the attention it warrants and that teachers have not been given the necessary tools for using CLT by teacher educators.

Glenn (2006) reported the practical difficulties of implementing a communicative approach when teaching English in English-as-a-foreign language (EFL) settings. These settings are the environments in which students have little exposure to English outside the classroom. Some reports attribute the failure of the approach to inadequacies of the teachers themselves.

\section{METHOD AND PROCEDURES}

\section{POPULATION AND THE SAMPLE OF THE STUDY}

The population of the study is EFL teachers at schools in AlKarkh First Education Directorate. The sample of the study is the EFL teachers (males and females) in 3 intermediate schools in the Amriah District. The total number of the EFL teachers was 29.

\section{RESEARCH INSTRUMENTS}

The researcher devised a questionnaire to measure EFL teachers' practices of the Communicative Language Teaching Approach in teaching speaking skills. The reliability and the validity of the questionnaire were computed.

\section{VALIDITY}

The questionnaire was given to a jury of 6 specialists in the given field. Five professors from the Faculty of Education Department of English, and also professors from different faculties at Baghdad University, in order to elicit their views as to accuracy, adequacy, and representation of the items and attitudes. Then the instrument was reviewed and modified based on the suggestions and comments provided by the experts.

\section{RELIABILITY}

A group of 4 male and 3 female teachers were chosen for a pilot study to ensure the reliability of questionnaire and determine if any of its items need to be modified after answering all the items of the questionnaire and provided their comments. After 5 days later the researcher distributed the questionnaire to the sample of the study once more. Cronbach alpha was used to calculate the internal reliability which was found to be 0.83 for the teachers' questionnaire.

\section{THE DEPENDENT VARIABLE}

The dependent variable is the teachers' actual practices of the Communicative Language Teaching methods inside the classroom.

The independent variable is the experience of the teachers.

\section{RESEARCH DESIGN}

In order to analyze the collected data, the researcher conducted the study by using the descriptive survey research design.

\section{STATISTICAL ANALYSIS}

The Statistical percentages were used to analyze the data in order to prove the hypothesis of the study. Each item of the teachers' questionnaire will follow by three options. These options give values that rank from 3 to 1 (Always $=3$, sometimes $=2$, never $=1$ ). For the contrasting items the opposite rank will be true.

\section{PROCEDURES OF THE STUDY}

This study carried out during the first semester of the school year 2018-2019. The researcher followed the following procedures:

1- The Department of English has provided the researcher with a letter to the schools' administrations to administer the questionnaire to the EFL teachers.

2- The validity and the reliability of the questionnaire were calculated.

3- A group of teachers were chosen for the pilot study.

4- The participants replied to the instrument inside the classroom to ensure unaided responses and to clarify any misconceptions.

5- An oral brief idea about the study and what is required, was given both to the teachers and the headmasters of the schools, in order to collect the data.

6- The researcher herself distributed the questionnaire to the EFL teachers.

7- The researcher collected the questionnaires to get the data computed and analyzed. 


\section{THE RESULTS AND DISCUSSIONS}

\section{RESULTS RELATED TO THE HYPOTHESIS OF THE STUDY}

To prove the hypothesis of the study "There is a high percentage of the implementation of communicative language teaching approach, strategies, and techniques in teaching speaking skills inside the classroom" a percentage ratio was used to analyze the items of the questionnaire. Table 1 shows the results.

\section{Table 1}

The percentages of the teachers' respond on the items of the questionnaire. $(\mathrm{F}=$ Frequency, and $\mathrm{P}=$ Percentage $)$

\begin{tabular}{|c|c|c|c|}
\hline Items & $\begin{array}{l}\text { F/P } \\
\text { (Always) }\end{array}$ & $\underset{\text { (sometimes) }}{\text { F/P }}$ & $\begin{array}{c}\text { F/P } \\
\text { (Never) }\end{array}$ \\
\hline $\begin{array}{l}\text { 1. I emphasize on communicative } \\
\text { competence. }\end{array}$ & $\begin{array}{l}9 /(31.03 \\
\%)\end{array}$ & $\begin{array}{l}17 /(58 . \\
62 \%)\end{array}$ & $3 /(10.34 \%)$ \\
\hline $\begin{array}{l}\text { 2. I start with grammar activities then } \\
\text { explain the meaning. }\end{array}$ & $8 /(27.58 \%)$ & $\begin{array}{c}15 / \\
(51.72 \%)\end{array}$ & $6 /(20.68 \%)$ \\
\hline $\begin{array}{l}\text { 3. I believe that brainstorming strategy } \\
\text { is a time -consuming. }\end{array}$ & $2 /(6.89 \%)$ & $\begin{array}{c}21 / \\
(72.41 \%)\end{array}$ & $6(20.68 \%)$ \\
\hline $\begin{array}{l}\text { 4. I focus on developing students } \\
\text { abilities to use language for different } \\
\text { purpose. }\end{array}$ & $21(72.41 \%)$ & $8 /(27.58 \%)$ & $0 \%$ \\
\hline $\begin{array}{l}\text { 5. I give a chance to students to initiate } \\
\text { free conversation. }\end{array}$ & $\begin{array}{c}15 / \\
(51.72 \%)\end{array}$ & $\begin{array}{c}10 / \\
(34.48 \%)\end{array}$ & $4 /(13.79 \%)$ \\
\hline $\begin{array}{l}\text { 6. I present the vocabulary in a list } \\
\text { form. }\end{array}$ & $\begin{array}{c}22 / \\
(75.86 \%)\end{array}$ & $s /(17.24 \%)$ & $2 /(6.89 \%)$ \\
\hline $\begin{array}{l}\text { 7. I emphasized on fluency more than } \\
\text { accuracy. }\end{array}$ & $2 /(6.89 \%)$ & $23(79.31)$ & $4 /(13.79)$ \\
\hline $\begin{array}{l}\text { 8. I provide immediate feedback for } \\
\text { students errors and mistakes. }\end{array}$ & $9 /(31.03 \%)$ & $18(62.60)$ & $2 /(6.89 \%)$ \\
\hline $\begin{array}{l}\text { 9. I encourage students to think in } \\
\text { Arabic then translate to English to } \\
\text { avoid committing mistakes. }\end{array}$ & $\begin{array}{c}10 / \\
(34.48 \%)\end{array}$ & $9 /(31.03 \%)$ & $10 /(34.48 \%)$ \\
\hline $\begin{array}{l}\text { 10.I practice conversation activity with } \\
\text { student individually. }\end{array}$ & $\begin{array}{c}10 / \\
(34.48 \%)\end{array}$ & $\begin{array}{c}19 / \\
(65.51 \%)\end{array}$ & $0 \%$ \\
\hline $\begin{array}{l}\text { 11. I encourage student to practice the } \\
\text { language outside the classroom. }\end{array}$ & $\begin{array}{c}19 / \\
(65.51 \%)\end{array}$ & $9 /(31.03 \%)$ & $1 /(3.44 \%)$ \\
\hline $\begin{array}{l}\text { 12. I focus on speaking skill more than } \\
\text { other skills }\end{array}$ & $6 /(20.68 \%)$ & $\begin{array}{c}22 / \\
(75.86 \%)\end{array}$ & $1 /(3.44 \%)$ \\
\hline 13. I evaluate students orally. & $10 /(34.48 \%)$ & $\begin{array}{c}15 / \\
(51.72 \%)\end{array}$ & $4 /(13.79 \%)$ \\
\hline $\begin{array}{l}\text { 14. I encourage students to work in } \\
\text { groups. }\end{array}$ & $\begin{array}{l}17 / \\
(58.62 \%)\end{array}$ & $\begin{array}{c}12 / \\
(41.37 \%)\end{array}$ & $0 \%$ \\
\hline $\begin{array}{l}\text { 15.I postpone writing skills until } \\
\text { speaking is mastered. }\end{array}$ & $8 /(27.58 \%)$ & $(58.62 \%)$ & $4 /(13.79 \%)$ \\
\hline $\begin{array}{l}16.1 \text { encourage students to speak by } \\
\text { practicing problem solving strategy. }\end{array}$ & $6 /(20.68 \%)$ & $\begin{array}{c}21 / \\
(72.41 \%)\end{array}$ & $2 /(6.89 \%)$ \\
\hline $\begin{array}{l}\text { 17. I give students time for negotiation } \\
\text { and discussion. }\end{array}$ & $\begin{array}{c}11 / \\
(37.93 \%)\end{array}$ & $\begin{array}{c}17 / \\
(58.62 \%)\end{array}$ & $1 /(3.44 \%)$ \\
\hline $\begin{array}{l}\text { 18. I prepare authentic materials to } \\
\text { explain new subject. }\end{array}$ & $\begin{array}{c}16 / \\
(55.17 \%) .\end{array}$ & $\begin{array}{c}12 / \\
(41.37 \%)\end{array}$ & $0 \%$ \\
\hline $\begin{array}{l}\text { 19. I encourage students to play } \\
\text { language game. }\end{array}$ & $\begin{array}{c}13 / \\
(44,82 \%)\end{array}$ & $\begin{array}{c}16 / \\
(55.17 \%)\end{array}$ & $0 \%$ \\
\hline $\begin{array}{l}\text { 20. I encourage students to do a role- } \\
\text { play. }\end{array}$ & $\begin{array}{c}11 / \\
(37.93 \%)\end{array}$ & $\begin{array}{c}18 / \\
(62.06 \%)\end{array}$ & $0 \%$ \\
\hline
\end{tabular}

Table 1 shows that English language teachers use communicative language teaching techniques, strategies, and activities sometimes and not always. The highest percentage is 79.31 and the lowest percentage is $3.44 \%$. The most high percentages are for the scale entitled "sometimes", such as: $58.62 \%$ of teachers emphasize on communicative competence; $72.41 \%$ believe that brainstorming strategy is wasting of time; while the negative item "I present the vocabulary in a list form" this item got the highest percentage $75.86 \% ; 58.62 \%$ of the teachers sometimes give students time for negotiation and discussion; $55.17 \%$ of teachers sometimes encourage students to play language games; finally, $62.06 \%$ of teachers sometimes encourage students to do a role-play.

\section{DISCUSSIONS OF THE RESULTS}

The results revealed that the teachers who teach English language in the intermediate schools use the communicative language teaching approach (CLT), methods, techniques, and activities in a very limited way. The results show that the teachers sometimes use the communicative language teaching techniques in teaching speaking skills. This is due to the large number of students in the classroom, which forces teachers to focus on fluency more than accuracy, because accuracy needs time and efforts. In fact the CLT focuses on both fluency and accuracy in teaching speaking skills, but the teachers sometimes use both of them. Concerning the brainstorming strategy which is the core of starting any CLT class, the results revealed that the English language teachers consider it as a time-consuming that the teacher use to being the lesson with it. The teachers are far from the features of CLT in teaching new vocabulary; they always present the vocabulary in a list form which is against the rules of teaching via CLT. Also, very few of the teachers encourage students to speak by the practicing problem-solving strategy, a strategy which is considered the core of practicing and generating ideas, but unfortunately less than $15 \%$ of the teachers use it in teaching speaking skills. Practicing the speaking skills rarely takes place inside the classroom in teaching speaking skills, less than $20 \%$ focus on speaking skill more than other skills in teaching speaking skills. Using the first language in teaching speaking skills is very frequent, just $34.48 \%$ never use it, and the other teachers use it in teaching speaking skills. Role play and games are the most important techniques that CLT focuses on, but unfortunately less than $50 \%$ of teacher use them in teaching speaking skills.

\section{CONCLUSION}

The findings of this research conclude that all CLT characteristics are being used in a limited way in teaching speaking skills. The teachers who teach speaking skills use the CLT sometimes in teaching speaking skills inside the classroom, even when they evaluate the students' speaking performance, they do not do it orally.

\section{RECOMMENDATIONS}

1- EFL classes should not exceed than 25 students.

2- The EFL classes should be equipped with the modern technology to help the teacher to use the CLT strategy inside the classroom.

3- Similar survey research in other skills to be carried.

4- Survey research on the obstacles that encounter the EFL teacher when using the CLT techniques.

\section{REFERENCES}

Brown, H. Douglas (2000). Teaching by Principles An Interactive Approach to Language $P$

Gatbonton, E.; Segalowitz, N. (2005). Rethinking Communicative Language Teaching: A Focus on Access to Fluency. Journal Articles Canadian Modern Language Review,(61).

Glenn, D. (2006). The Communicative Approach: Addressing Frequent Failure. Bureau of Educational and Cultural Affairs. Available at: http://exchanges.state.gov.

Joyce, C (2005). Exploring English Teachers' Beliefs and Practical Knowledge about Communicative Language Teaching in EFL Contexts. doctoral thesis, Language Education at Indiana University. Available at: http://www.abacon.com.

Kumaravadivelu, B. (1993). Maximizing learning potential in the communicative classroom. ELT Journal 46 (1): 12-21. 
Leng, H. (1997). New bottles, old wine: Communicative language teaching in China. English Teaching Forum. Available at:http://exchanges.state.gov

Nunan, D. (1991). Communicative tasks and the language curriculum. TESOL Quarterly (25).

Pandey S.K. (2003). Teaching Communication. Ajay Verma for Commonwealth Publisher. New Delhi.

Rao, Z. (2002). Chinese students' perceptions of communicative and noncommunicative activities in EFL classroom System. Asian-efl-journal (30). available at: http://www.asian-efl-journal.com

Savignon, S. J. (2002). Interpreting communicative language teaching: Contexts and concerns in teacher education. New Haven: Yale University Press. Available at: http://www.people.iup.edu

Tim, B. (1999). Small Group Communication Moorhead State retrieved from http://www.abacon.com

Wilkins, KG. (1999) Development discourse on gender and communication in strategies for social change. Journal of Communication. Retrieved from http://www.search.ebscohost.com

Whitley, S.(1983). Spanish/English Contrasts: A Course in Spanish Linguistics. Georgetown UP. Available at: http://www.eric.ed.gos 